\title{
Konsep Pendidikan Ki Hajar Dewantara dan Relevansinya dengan Pendidikan Madrasah Ibtidaiyah
}

\author{
Edwin Firmansyah ${ }^{1}$, Zubaedah Nasucha², Suci Muzfirah ${ }^{3}$ \\ 1,2STPI Bina Insan Mulia Yogyakarta \\ 3UIN Sunan Kalijaga Yogyakarta \\ (syahedwin06@gmail.com),(zubaedah stpi@yahoo.com). \\ (sucimusoffah15@gmail.com)
}

\begin{abstract}
This study focuses on the concept of Ki Hajar Dewantara's thinking for its relevance to education in Mi at this time. MI. Practically, this research is expected to provide clarity on the concept of education according to Ki Hajar Dewantara, thus providing a bright spot on its relevance to education at MI today, and can contribute to finding solutions to the problems that are being faced by the Indonesian nation. This research is a qualitative research with the type of library research, namely exploring Ki Hajar Dewantara's thoughts on education. The data collection technique that the author uses is to collect books, journals and others related to the subject matter. The data that has been collected was analyzed using descriptive methods, namely research methods that seek to reveal the facts of an event, object, activity, and process. The results of this study indicate that Ki Hajar's educational concept is still relevant today. Judging from his thoughts in accordance with the concepts that are still being implemented, namely education and teaching which is a deliberate effort to liberate the outer and inner aspects of humans.
\end{abstract}

Keywords: Education Concept, Ki Hajar Dewantara, Madrasah Ibtidaiyah

\section{Abstrak}

Penelitian ini mempunyai fokus pada konsep pemikiran ki Hajar Dewantara untuk relevansinya terhadap pendidikan di Mi pada saat ini. Penelitian ini secara teori ingin menyumbanngkan pemikiran terhadap pendidikan di MI khususnyya dan kepada masyarakat secara uumuumnya, khususnya dapat mengembangkan wawasan pengetahuan dan pola fikir para pendidik di tingkat MI. Secara praktis, penelitian ini diharapkan dapat memberikan kejelasan mengenai konsep pendidikan menurut Ki Hajar Dewantara, sehingga memberikan titik terang atas relevansinya dengan pendidikan di MI saat ini, serta dapat memberikan sumbangsih dalam mencarikan solusi atas permasalahan yang tengah dihadapi bangsa Indonesia. Penelitian ini merupakan penelitian kualitatif dengan jenis penelitian kepustakaan (library research) yaitu menggali pemikiran Ki Hajar Dewantara tentang pendidikan. Teknik

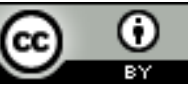




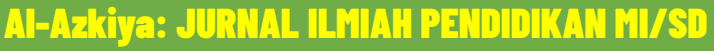 \\ ISSI: Print (2145-1656) Online (2521-8110) \\ Vol. 6 Ilo.22021 \\ DOI 10.32505/al-akkiva.v62.2.3056}

pengumpulan data yang penulis gunakan adalah dengan mengumpulkan buku, jurnal dan lainnya yang terkait dengan pokok pembahasan. Data yang telah terkumpul dianalisis dengan menggunakan metode deskriptif yaitu metode penelitian yang berusaha mengungkap fakta suatu kejadian, objek, aktivitas, dan proses. Hasil penelitian ini menunjukkan bahwa konsep pendidikan Ki Hajar tersebut masih relevan hingga saat ini. Dilihat dari pemikiran-pemikiran beliau yang sesuai dengan konsep yang masih diimplementasikan yaitu pendidikan dan pengajaran yang merupakan upaya yang disengaja untuk memerdekakan aspek lahiriah dan batiniah manusia.

Kata Kunci: Konsep Pendidikan, Ki Hajar Dewantara, Madrasah Ibtidaiyah

\section{PENDAHULUAN}

Pendidikan digunakan untuk mengembangkan potensi cipta, rasa, maupun karsa seseorang agar menjadi nyata dan dapat berfungsi dalam perjalan hidupnya (Sugiarta et al., 2019). Upaya tersebut dimulai pertama kali oleh keluarga sejak dari dalam kandungan sampai lahir. Pendidikan keluarga terutama oleh orangtua berperan penting dalam mewujudkan awal pemahaman dan pengetahuan anak. Selanjutnya, anak akan mengembangkan pemahamannya dari rumah ke lingkungan baik di sekolah dan masyarakat. Jadi dapat dikatakan bahwa konsep berarti kegiatan akal untuk menangkap sesuatu (Utami, 2017).

Pendidikan menuntun segala kekuatan kodrat yang ada pada anak agar mereka dapat mencapai keselamatan dan kebahagiaan yang setinggi tingginya (Dewantara, 1977). Pendidikan yang bermutu dapat menyeimbangkan antara akal dan jiwa sehingga seseorang mampu membangun nilai kebaikan dalam masyarakat yang majemuk (Suwahyu, 2018). Dalam mewujudkan pendidikan yang bermutu, karakter yang kuat perlu menjadi pondasi yang kuat dari diri.

Pendidikan karakter ini perlu ditanamkan oleh guru di dalam kelas maupun masyarakat kepada siswa yang mulai tergerus arus global. Memasuki abad ke 21 kemajuan ilmu pengetahuan dan teknologi berkembang pesat sehingga membawa perubahan pada kurikulum dengan perbaikan sistem pendidikan. Pendidikan dengan sistem among yang telah digagas oleh Ki Hajar Dewantara sebelumnya membawa pembaruan pada pendidikan abad ke 21. Pembelajaran abad ke 21 peserta didik 
dituntut untuk mendorong peserta didik agar memiliki keterampilan berpikir kreatif (Nurhalita \& Hudaidah, 2021).

Salah satu tujuan dari pendidikan di Indonesia, yaitu terbentuknya generasi yang cerdas dan berkarakter. Namun, hal tersebut belum diimbangi dengan sistem pendidikan yang tepat, sehingga saat ini masih banyak terjadi permasalahan seperti terjadinya perundungan dan kekerasan dalam dunia pendidikan, bahkan kecurangan juga terjadi dalam dunia pendidikan. Permasalahan tersebut menjadi tanggung jawab bersama, sehingga dibutuhkan semangat kesadaran tentang pentingnya pendidikan (Ainia, 2020). Dalam hal pendidikan itu bukan hanya sekedar memberikan ilmu pengetahuan kepada muridnya, akan tetapi lebih luas dari itu yakni mentransfer nilai. Selain dari itu pendidikan dapat diartikan sebagai kebudayaan agar selalu menggali dan memajukan potensi dan kekreatifan yang dimilikinya (Idris, 2014).

Berpikir menjadi suatu keutamaan bagi transformasi kehidupan seorang manusia secara internal yang berhubungan dengan refleksi diri, sedangkan eksternal menyangkut bagaimana hubungan dengan pihak luar diri. Dalam konteks tersebut, pemikiran Ki Hajar Dewantara mengenai pendidikan awal mulanya adalah upaya berpikir guna menyiasati terwujudnya kehidupan yang bernilai bermakna, bersahaja, dan bermartabat atau disebut dengan pendidikan yang berkarakter (Subandi, 2017). Namun, seiring dengan konsep pemikiran manusia yang bermacam-macam dan dipandang cocok dengan pendidikan di suatu tempat dan waktu tertentu, belum tentu dapat dihubungkan dengan tempat dan waktu yang berbeda. Dan hal tersebut berlaku bagi gagasan Ki Hajar Dewantara mengenai pendidikan.

Upaya seperti itu memang sulit, karena timbulnya persoalan-persoalan pendidikan saat ini tidak lepas dari usaha menanggapi tantangan modernisasi layaknya yang dilaksankan oleh Ki Hajar Dewantara pada masa dulu. Maka, dalam penelitian ini penulis memusatkan perhatian pada konsep-konsep Ki Hajar Dewantara mengenai pendidikan dan kerelevansinya terhadap pendidikan di Indonesia masa

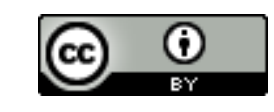


sekarang. Dengan tujuan agar menemukan relevansi konsep pendidikan di Madrasah Ibtidaiyah.

\section{METODE PENELITIAN}

Rancangan penelitian ini merupakan kajian studi pustaka dengan menggunakan pendekatan content analysis (analisis isi). Sumber data dalam penelitian ini berupa sumber primer dan sekunder dimana sumber primer meliputi kumpulan karya Ki Hajar Dewantara. Sumber sekunder berupa tulisan atau karua orang lain tentang Ki Hajar Dewantara. Pengumpulan data dilakukan dengan teknik library research (penelitian pustaka). Data yang telah terkumpul kemudian dianalisis secara kualitatif degan pendekatan induktif dengan mengacu pada permasalahan yang ada.

\section{HASIL DAN PEMBAHASAN}

\section{Riwayat Hidup dan Pendidikan Ki Hajar Dewantara}

Puji Nur Utami menuliskan biografi Ki Hajar Dewatara. Beliau dilahirkan di Yoyakarta pada hari Kamis tanggal 2 Mei 1889. Pada masa kanak-kanak nama beliau adalah Raden Mas Suwardi Suryaningrat. Ayah beliau bernama Pangeran Suryaningrat yang merupakan putra sulung Sri Paku Alam ke-III (Utami, 2017). Ibu beliau yakni permaisuri. Dengan demikian, Kemudian beliau menikah dengan Raden Ajeng Sutartinah, putri dari Gusti Pangeran Harjo Sasraningrat, adik dari Gusti Pangeran Harjo Suryaningrat (ayah Suwardi). Dengan demikian, Suwardi dan Sutartinah adalah saudara sepupu. Jadi, keduanya merupakan cucu Paku Alam III.

Dalam karya ilmiah oleh Bartolomeus Samho, saat masa kanak-kanak Ki Hajar Dewantara sudah belajar dengan suasana religi. Masalah kekurangan materi keluarganya, tidak menjadikan surutnya semangat belajar beliau. Beliau hanya masuk ke Sekolah Dasar Belanda III. Kemudian setelah tamat tahun 1904, Ki Hajar Dewantara mengalami kekhawatiran untuk meneruskan pendidikannya. Selain kebingungan beliau karena masalah siapa yang akan membiayai sekolahnya, beliau

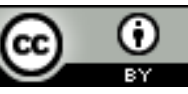


juga kebingungan beliau akan kemana pula beliau harus meneruskan sekolahnya. Dapat di maklumi, keluarga beliau tidak cukup berada dibandingkan dengan kerabat Paku Alam yang lain. Selain itu, ayah beliau yang cacat netra (mata) menjadi salah satu alasan terkait masalah pendidikannya. Ki Hajar sempat masuk sekolah guru di Yogyakarta, tetapi tidak selesai, dan selama menempuh sekolah tersebut, datanglah tawaran beasiswa untuk menjadi dokter. Kesempatan itu dengan sengaja di terima Ki Hajar Dewantara.

Selama masa kira-kira lima tahun di tahun 1905-1910 beliau menempuh pendidikan di sekolah Dokter Jawa, akan tetapi beliau tidak sampai menyelesaikan pendidikannya dikarenakan sakit keras yang cukup lama. Dan selama sakit beliau pasti tidak dapat fokus memahami pelajaran, akibat yang timbul adalah beliau tidak naik kelas. Dan beasiswa beliau ditarik kembali. Beliau meninggalkan sekolahnya dengan terpaksa karena tidak mampu membiayainya. Tetapi karena kepandaian beliau dalam bahasa Belanda, membuat Direktur Sekolah beliau terdorong mengeluarkan surat istimewa yang menjelaskan bakat beliau tersebut.

Saat genap usia 40 tahun tanggal 3 Februari 1928 Raden Mas Suwardi Suryaningrat berganti nama menjadi Ki Hajar Dewantara dan Raden Ajeng Sutartinah berganti nama menjadi Nyi Hajar Dewantara. Sejak itu, beliau tidak menggunakan gelar kebangsawanan didepan namanya. Hal tersebut dimaksudkan agar beliau dapat bebas dekat dengan rakyat, baik secara fisik maupun hatinya. Dan tak lama setelah kembalinya beliau ke kampung halaman, tepatnya pada tanggal 26 April 1959 beliau wafat dan jenazahnya dikebumikan di makam Wijayabrata, yakni makam keluarga Taman Siswa. Dan untuk mengenang jasa dan perjuangannya dibidang pendidikan maka hari lahir Ki Hajar Dewantara tanggal 2 Mei sampai saat ini di peringati sebagai Hari Pendidikan Nasional (Hardiknas). 


\section{Konsep Pendidikan Menurut Ki Hajar Dewantara}

Gagasan Ki Hajar Dewantara tentang pendidikan sudah menjadi citra tersendiri untuk sejarah pendidikan Indonesia. Ki Hajar Dewantara adalah seorang pencetus pendidikan klasik Indonesia (Yanuarti, 2017). Ciri utama dari pendidikan yang berpusat pada siswa adalah bahwa guru menghormati siswa. Hal ini yang disebut dengan pendidikan yang sesuai dengan pemikiran beliau. Pendidikan menurut Ki Hajar Dewantara yaitu agar pendidikan tidak membuang pokok kebudayaan yang menjadikan asing dengan realita pada anak didik. Pendidikan harus membuat manusia di Indonesia mempunyai sifat peka dalam hal budi pekerti. Sifat peka ini yang akan menjadikan manusia di Indonesia terbentuk menjadi pribadi berbudi pekerti serta berkeheningan batin.

Ketika memutuskan terjun ke dunia pendidikan, tujuan utama yang ingin dicapai Ki Hajar Dewantara dari pendidikan itu adalah terbentuknya generasi bangsa Indonesia yang mandiri, penuh daya kreasi dan berbudi pekerti mulia. Tetapi beliau sadar, jika pendidikan yang mengedepankan budi pekerti tidak hanya menjadi tanggung jawab sekolah saja, tapi juga menjadi tanggungjawab masyarakat dan keluarga. Hal itu kemudian membuatnya memiliki gagasan untuk membuat konsep pendidikan yang melibatkan ketiga lingkungan itu. Konsep pendidikan yang dilaksanakan Ki Hajar Dewantara itu diberi nama "Tri Pusat Pendidikan", yaitu suatu pelaksanaan pendidikan dengan melibatkan alam keluarga, alam perguruan, dan alam masyarakat untuk membentuk manusia-manusia yang unggul, berbudi pekerti dan cerdas.

Bangsa yang maju tak dapat dijauhkan dari cara pandang dan cara berfikirnya yang mencerminkan kesadarannya akan pentingnya memajukan sektor pendidikan sebagai tujuan pokok kebangsaan. Saat ini masalah terkompleks bangsa Indonesia yakni penyesuaian merancang dunia yang penuh dengan masalah yang makin kompleks dan sulit diramalkan. Di Indonesia sudah cukup banyak orang yang "pintar",

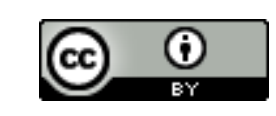


tapi sulit menemukan orang yang "benar". Ini masalah yang harus disadari sebagai masalah yang serius bagi perkembangan pendidikan.

\section{Karya Tulis Ki Hajar Dewantara}

Ki Hajar Dewantara menulis menulis beberapa karya beliau, dikarenakan kepedulian beliau pada pendidikan dan kebudayaan. Dan karyakarya tersebut yang hingga sekarang masih banyak digunakan sebagai rujukan penelitian tentang pendidikan dan kebudayaan.

a. Buku pertama yakni membahas Pendidikan. Buku ini khusus membahas tentang gagasan dan pemikiran beliau dalam bidang pendidikan diantaranya tentang hal Pendidikan Nasional yang bermanfaat bagi kehidupan bersama dengan kemerdekaan manusia menjadi anggota dari persatuan rakyat (Dewantara, 1977).

b. Buku kedua membahas Kebudayaan. Isi dari buku ini memuat tulisan-tulisan mengenai kebudayaan dan kesenian. Kebudayaan sering juga dengan kultur yang artinya adalah buah dari keadabanmanusia atau suatu usaha perbaikan hidup manusia. Kultur atau kebudayaan itu mempunyai berbagai macam sifat, tetapi karena semuanya adalah adab, maka semua kebudayaan atau kultur itu selalu bersifat tertib (Dewantara, 1967).

c. Buku ketiga yaitu membahas tentang Politik dan Kemasyarakatan. Isi buku ini memuat tulisan mengenai politik antara tahun 1913-1922 yang menggegerkan dunia imperialis Belanda, dan tulisan mengenai pemuda dan perjuangannya.

d. Buku keempat membahas tentang Riwayat dan Perjuangan Hidup Penulis: Ki Hajar Dewantara yang menjabarkancerita kehidupan dan perjuangan hidup perintis dan pahlawan kemerdekaan Ki Hajar Dewantara (Utami, 2017).

\section{Pemikiran Ki Hajar Dewantara dalam Pendidikan di Indonesia}

Menurut Suroso dalam jurnal Scholaria, "Ki Hajar Dewantara merupakan satu dari sedikit tokoh yang secara intens mencurahkan perhatiannya dibidang pendidikan dimasa pergerakan dan awal kemerdekaan" (Suroso, 2011). Dalam karya ilmiah jurnal 
tentang filsafat pendidikan Ki Hajar Dewantara dan sumbangannya bagi pendidikan Indonesia oleh Henricus Suparlan, Pandangan Ki Hadjar Dewantara tentang belajar yaitu: "Pandangan Ki Hadjar Dewantara tentang belajar terlihat pada konsep mengenai Tri Pusat Pendidikan, bahwa anak didik tidak semata-mata hanya belajar di sekolah tapi juga dalam keluarga dan masyarakat (dalam alam pemuda). Pendidikan keluarga mendidik anak-anak dengan sebaik mungkin yang meliputi jasmani dan rohani. Keadaan keluarga sangat mempengaruhi perilaku pendidikan yang diupayakan dalam keluarga" (Suparlan, 2015).

Memajukan bertumbuhnya budi pekerti yang dengan kata lain disebut dengan karakter yaitu berarti jiwa yang sudah berazaz hukum kebatinan. Orang yang sudah memiliki sifat budi pekerti itu pasti selalu memikirkan dan merasakan segala sesuatu dengan menggunakan ukuran dan dasar-dasar yang sudah ditetapkan. Budi pekerti bukan konsep yang bersifat teori tentang baik buruk, baik salah, seperti yang dipahami oleh masyarakat luas. Akan tetapi pengajaran budi pekerti mengandung maknapentransfer materi tentang kehidupan jiwa atau perikeadaban manusia. Atau dengan kata lain, kaharusan memberi keterangan dan penjelasan mengenai budi pekerti secara lebih luas (Muthoifin \& Jinan, 2015).

Kemudian seorang yang berpikir maju adalah yang berpikir cerdas kognisi/ tahu banyak dan banyak tahu dan kecerdasannya itu memerdekakan diri dari jenis-jenis pembodohan. Manusia yang sehat fisik adalah selain sehat secara jasmani, juga lebih mempunyai pemahaman yang baik tentang fungsi tubuhnya dan memahami fungsi tersebut untuk membebaskan diri dari segala dorongan kearah tindakan kejahatan. Manusia yang sehat fisiknya mampu mengendalikan dorongan-dorongan dan tuntutan tubuh. Dengan melalui pengendalian tersebut, berpikir maju dan berbudi pekerti maju mendapat dukungan untuk menyatakan kebebasan diri dari segala bentuk penindasan diri yang serakah di satu sisi dan memiliki kemampuan untuk menegaskan diri. Jadi kemajuan fisik dipahami sebagai kekuatan untuk memperjuangkan kebebasan dan keterampilan (Samho \& Yasunari, 2010).

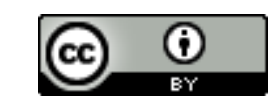




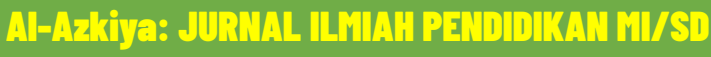 \\ ISSI: Print (2145-1656) Online (2521-8110) \\ Vol. 6 Klo.2 2021 \\ DOI $10.32505 / \mathrm{al}-\mathrm{arki}$ a.v6i2.3056}

Keluarga adalah pusat dari pendidikan awal dan terpenting, karena keluarga sangat berpengaruh bagipertumbuhan sikap budi pekerti setiap manusia. Tujuan pendidikan di keluarga adalah memberi nasehat, anjuran yang bisa mengarahkan anak pada perbuatan baik, kepribadian yang baik, dan juga mampu menguasai diri sendiri untuk mencapai kebahagiaan lahir dan batin, dunia dan akhirat (Yohana, 2017).

Lingkungan sekolah adalah kelanjutan dari alam keluarga. Di sekolah ini, tugas pendidikan diserahkan kepada pengajar seperti guru, dan sebagainya. Di sekolah anak mendapatkan berbagai informasi tentang ilmu pengetahuan dan bakat yang perlu dikembangkan dalam kehidupannya. Orang tua mengajar dan mendidik anaknya hanya sebatas di rumah, tetapi seorang guru mengajarkan ilmunya di sekolah, majelis-majelis ilmu, atau rumah-rumah yang memungkinkan menyelenggarakan pendidikan dan pengajaran.

Tri Pusat yang selanjutnya adalah pemuda/masyarakat. Pada hakikatnya masyarakat adalah suatu kumpulan dari keluarga yangsatu dan lainnya terkait oleh tatanan aturan. Masyarakat merupakan suatu alat penghubung sosial yang mempunyai dampak yang besar dalam pengembangan dan pemberdayaan potensi anak didik. Dan di dalam suatu masyarakat terdapat beberapa organisasi, lembaga, perkumpulan yang dari itu semua menjadi wadah dan peluang untuk mendapat pengalamanpengalaman dan pertukaran pikiran masyarakat. Masyarakat/ pemuda harus diakui dan digunakan untuk menyokong pendidikan.

Dalam pergerakannya orang tua hanyalah sebagai penasehat dan pemberikebebasan secukupnya pada pemuda. Orang tua hanya mengamati dan bertindak jika memang sudah diperlukan. Pergerakan pemuda jaman sekarang semakin terlihat memisahkan anak-anak dengan alam keluarganya, dan ini yang akan menjadikan bahaya bagi diri pemuda itu sendiri, juga jika pendidikan yang berkedok ke barat-baratan yang dialami sebagian besar dari anak-anak. Dimana seharusnya pemuda itu membentuk sebuah pergerakan yang dapat menyokong untuk pendidikan

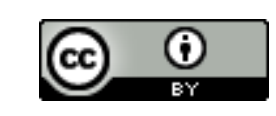


menuju kecerdasan budi pekerti. Maka pergerakan pemuda perlu untuk diakui sebagai pusat pendidikan.

\section{Tiga Fatwa Pendidikan}

Pendidikan nasional menurut paham Ki Hajar Dewantara, dalam Taman Siswa yakni pendidikan yang berlandaskan garis kehidupansuatu bangsa yang ditujukan bagi keperluan kehidupan yang bisa menjunjung derajat Negara dan rakyat, agar Indonesia dapat bekerjasama demi kemuliaan manusia di seluruh dunia. Maka, Ki Hajar Dewantara mengunggulkan ajaran tentang pendidikan atau yang biasa disebut dengan tiga fatwa Ki Hajar Dewantara, yaitu: Pertama, artinya ketetapan pikiran dan batin itulah yang akan menentukan kualitas manusia. Dan jika tetep dan antep itu sudah ada, maka mantep yang berarti tidak dapat diundur lagi akan menyusul (Dewantara, 1977). Tetep dimaknai ketetapan berpikir komitmen. Artinya pikiran tidak mudah goyah oleh pikiran baru yang tidak sesuai dengan nilai-nilai pendidikan. Sementara antep diartikan sebagai kepercayaan diri untuk terus berpikir maju untuk menghadapi bermacam-macam tantangan hidup. Sedangkan mantep diartikan memiliki orientasi jelas menuju tujuan pasti, yaitu kebebasan diri sebagai pribadi, masyarakat, dan dunia.

Kedua, ngandel artinya percaya akan memberikan pendirian yang teguh yang kemudian kendel (berani) dan bandel (tidak lekas ketakutan, tawakal) akan menyusul sendiri. Ngandel diartikan sebagai teguh pendirian, karena pendidikan itu harus dengan kondisi diri yang teguh pendirian atau orang yang mempunyai prinsip dalam hidupnya. Dan pendidikan juga menjadikan manusia agar menjadi pribadi yang berwibawa dalam menegakkan kebenaran dan keadilan atau disebut dengan istilah kendel. Kemudian istilah bandel menunjukkan bahwa seorang yang terdidik adalah yang tahan uji, segala cobaan dengan tawakal, tidak lekas ketakutan.

Ketiga, artinya kesucian pikiran dan kebatinan, dan kalau sudah ada tigatiganya itu, maka kemenangan akan jadi kebahagiaan tersendiri. Fatwa ketiga ini dapat pula diartikan bahwa pendidikan pada tataran terdalam yang bercorak religius.

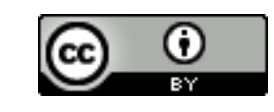


Pendidikan itu menciptakan perasaan (neng), keheningan (ning), ketenangan (nang), dan renungan (nung). Menurut beliau, kekuasaan akan datang saat seseorang telah mengalami kesucian pikiran dan ketenangan batin serta hati.

Fatwa Ki Hajar Dewantara tersebut tetap penting karena memiliki arti yang berkualitas kemanusiawian. Fatwa tersebut tetap terlihat mempunyai relevansi bagi konteks pendidikan Indonesia saat ini terutama jika penerapannya ditujukan membangun jiwa seorang pemimpin dalam diri anak-anak Indonesia. Artinya, mereka bisa menjadi pemimpin yang memiliki kepercayaan diri dan pendirian yang teguh, memiliki pikiran suci, batin yang tenang dan hati yang senang. Kondisi demikian menjadi jaminan kearah terciptanya kepemipinan yang memerdekakan kemanusiaan setiap pribadi di Indonesia secara utuh dan penuh.

\section{Semboyan dan Metode}

Meskipun Ki Hajar Dewantara belajar kependidikan di barat, yang dasarnya berupa perintah, hukuman dan ketertiban yang bersifat paksaan, beliau tidak ingin menggunakan sistem pendidikan barat tersebut di Indonesia. Dalam pendidikan di Indonesia menurut beliau tidak memakai dasar "perintah", akan tetapi memakai dasar tertib dan damai. Bangsa Indonesia selalu menjaga atas berlangsungnya kehidupan batin anak, dan harus dijauhkan dari sikap paksaan. Dasar "hukuman" itu maksudnya untuk mencegah kejahatan. Itulah tandanya setiap peraturan tidak akan bisa sempurna. Sedangkan "ketertiban" dalam pendidikan Barat jelas sudah hanya hukuman dan paksaan. Oleh karena itu dasar pendidikan kita menjadi tertib dan damai.

Menurut Ki Hajar Dewantara, metode pendidikan yang cocok dengan karakter orang Indonesia adalah tidak dengan paksaan. Orang Indonesia yang termasuk bagian dari bangsa timur adalah memakai nilai-nilai tradisional yang berupa kehalusan rasa, hidup dengan kasih sayang, cinta akan kedamaian, dan sopan dalam tutur kata serta tindakan. Nilai-nilai tersebut telah dimulai dari anak yang masih

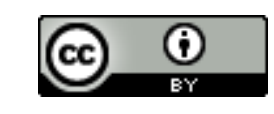




\section{Al-Akkija: JURWAL ILFIAH PEHDIDIKAW KIISD \\ ISSI: Print (2145-1656) Online (2521-8110) \\ Vol. 6 Klo.2 2021

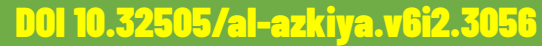

berusia dini. Semua itu menjadi syarat kita akan berusaha mendatangkan rakyat yang merdeka, dalam arti yang sebenar-benarnya yaitu: lahirnya tidak terperintah, batinnya bisa memerintahkan sendiri dan dapat berdiri sendiri karena kekuatan sendiri. Oleh karena bangsa Indonesia berdasar pada nilai tradisional tersebut, maka Ki Hajar Dewantara menerapkan tiga semboyan pendidikan yang hingga saat ini menjadi kekhasan tersendiri bangsa Indonesia yang tidak mengikut pada metode barat. Tiga semboyan tersebut adalah: Ing Ngarsa Sung Tulada, Ing Madya Mangun Karsa, Tut Wuri Handayani

Kemudian dari beberapa penjelasan diatas, secara tersirat dijelaskan bahwa Ing Ngarsa Sung Tulada, Ing Madya Mangun Karsa, Tut Wuri Handayanibermakna pribadi seseorang yang baik adalah disamping menjadi suri tauladan atau panutan, tetapi juga harus mampu menggugah semangat dan memberikan dorongan moral dari belakang agar orang-orang disekitarnya bisa merasakan situasi yang baik dan bersahabat, sehingga kita dapat menjadi manusia yang bermanfaat di masyarakat.

Ketiga semboyan tersebut apabila kita maknai serta hayati bersama merupakan akar dan ujung tombak dari peran serta guru dalam menjalankan roda pendidikan nasional. Semboyan inipun sejalan dengan yang diuraikan oleh Abidin dalam (Susilo, 2018) bahwa tugas dan fungsi guru didalam kelas tidak hanya transfer of knowledge, akan tetapi inti dari tugas guru adalam mengembangkan, mengarahkan dan memberikan motivasi.

\section{Asas-asas Pendidikan}

Dalam konsep pendidikan karakter menurut Ki Hajar Dewantara yang ditulis oleh Puji Nur Utami penjelasan mengenai asas-asas tersebut yaitu Pertama, asas kodrat alam atau asas tertib damai. Menurut Ki Hajar Dewantara, asas tersebut adalah asas mengenai hak seseorang untuk mengatur dirinya sendiri dengan mengingat tertibnya. Dalam konteks tersebut, pendidikan harus dilaksanakan dengan maksud pemeliharaan atas dasar perhatian yang besar kepada kebebasan anak untuk 
bertumbuh lahir batinnya sesuai dengan kodratnya. Dan secara kodratnya, fikiran manusia itu bisa berkembang dan dengan pengembangan kemampuan berfikir manusia secara sengaja itulah yang dipahami dan dimengerti sebagai pendidikan.

Kedua, asas kemerdekaan ini mengandung arti bahwa pengajaran berarti mendidik peserta didik menjadi manusia yang memiliki kebebasan pada batinnya, pikirannya, dan juga tenaganya. Dalam pemikiran beliau asas kemerdekaan berkaitan dengan upaya membentuk peserta didik menjadi pribadi yang memiliki kebebasan yang bertanggung jawab sehingga menciptakan keselarasan dengan masyarakat.

Ketiga, asas kebudayaan ini berdasar pada keyakinan kodrati bahwa manusia adalah makhluk berbudaya dan kebudayaan tersebut merupakan ciri khas seseorang. Menurut Ki Hajar Dewantara, kebudayaan itu tidak memiliki bentuk abadi, melainkan terus menerus berganti-ganti wujudnya. Salah satu penyebabnya adalah karena bergantinya alam dan masa yakni sebagai petunjuk arah dan pedoman untuk mencapai keharmonisan sosial di Indonesia.

Keempat, asas kebangsaan merupakan ajaran Ki Hajar Dewantara yang amat penting sebagai bagian dari wawasan kemanusiaan. Dalam konteks tersebut, asas ini diperjuangkan Ki Hajar Dewantara untuk mengatasi segala perbedaan yang tumbuh dan berkembang berdasarkan daerah, suku, keurunan, ataupun keagamaan. Rasa kebangsaan adalah bagian rasa kebatinan kita manusia, yang hidup dan dihidupkan dalam jiwa kita dengan disengaja. Kehormatan bangsa adalah kehormatan diri kemudian seterusnya.

Kelima, asas kemanusiaan yang pada dasanya mengandung makna persahabatan antar bangsa-bangsa. Dalam konteks ini, ia menggaris bawahi pentingnya bangsa Indonesia menjalin persahabatan dengan bangsa-bangsa lain. Asas kemanusiaan ini boleh dipandang sebagai asas yang radikal sebab konsep kemanusiaa itu merupakan akar dan sekaligus titik simpul bagi proses hidup yang manusiawi. Padahal, kebutuhan manusia sangat beragam jenisnya termasuk didalamnya pemenuhan harkat kemanusiaan. 
Dasar belajar atau asas yang digagas oleh Ki Hajar Dewantara dalam perguruan taman siswa adalah panca dharma yaitu, asas kemerdekaan, asas kodrat alam, asas kebudayaan, asas kebangsaan, dan asas kemanusiaan seperti yang telah diuraikan. Asas belajar Ki Hadjar Dewantara merupakan bentuk perlawanan pada masa penjajahan. Asas tersebut dibentuk dengan tujuan agar manusia Indonesia pada masa itu memiliki keberanian untuk membebaskan diri dari penjajahan. Hal tersebut dapat dilihat dari karakteristik point yang lebih bersifat nasionalistik (Mujito, 2014).

Berbeda dengan prinsip belajar yang digunakan oleh Islam. Prinsip Islam dibentuk berdasarkan pengembangan fitrah manusia. Namun, kedua pendapat tersebut tidak bertentangan dengan pendapat Islam karena, hakikat dari pendapat Ki Hadjar Dewantara ada dalam pendapat Islam.

\section{Relevansi Pemikiran Ki Hajar Dewantara dengan Pendidikan di MI}

Melihat pemikiran ki hajar dewantara yang ingin memajukan pendidikan di Indonesia dengan asas persatuan tanpa membedakan ras, budaya, bangsa dan agama, pemikiran tersebut perlu ditanamkan sejak usia dini. Konsep pemikiran tersebut memberikan gambaran bahwa seorang guru harus memiliki jiwa Ing Ngarsa Sung Tulada, Ing Madya Mangun Karsa, Tut Wuri Handayani bermakna pribadi seseorang yang baik adalah disamping menjadi suri tauladan atau panutan, tetapi juga harus mampu menggugah semangat dan memberikan dorongan moral dari belakang agar orang-orang disekitarnya bisa merasakan situasi yang baik dan bersahabat, sehingga kita dapat menjadi manusia yang bermanfaat di masyarakat.

Menjadi suri tauladan ing ngarso sung tulada memberikan contoh kepada siswa dalam sebua pembelajaran di MI, tidak hanya memberikan materi tanpa dilaksanakan oleh peserta didik namun mampu mengimplementasikannya dalam kehidupan seharihari. Ing Madya Mangun Karsa menjadi pengguga semangat para peserta didik. Karena peserta didik tidak selamanya dalam kondisi yag semangat dalam belajar, maka seorang pendidik di MI harus mampu menjadi penyemangat bagipara peserta

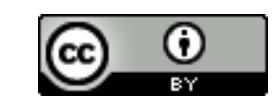


didik. Tut Wuri Handayani menjadi pendorong moral dan akhlak peserta didik moral dan eitika harus di ajarkan dan di berikan kemudian dibiasakan kepada peserta didik sejak dini karena usia-usia di pendidikan MI adalah usia emas dimana dalam pembentukan nilai kepada peserta didik sejak dini akan terbiasakan ketika dewasa nanti.

Menurut Ki Hadjar Dewantara manusia memiliki daya jiwa yaitu cipta, karsa, dan karya. Pengembangan manusia seutuhnya menuntut pengembangan semua daya secara seimbang. Pengembangan yang terlalu menitikberatkan pada satu daya saja akan menghasilkan ketidakutuhan perkembangan sebagai manusia. Ki Hadjar Dewantara mengatakan bahwa pendidikan yang menekankan pada aspek intelektual belaka hanya akan menjauhkan peserta didik dari masyarakatnya. Sementara itu, Pendidikan Agama Islam di sekolah atau madrasah bertujuan untuk menumbuhkan dan meningkatkan keimanan. Hal tersebut dilakukan melalui pemberian dan pemupukan pengetahuan, penghayatan, pengamalan, serta pengalaman tentang agama Islam sehingga menjadi muslim yang berkembang dalam hal keimanan, ketakwaan, berbangsa, serta untuk melanjutkan pada jenjang pendidikan yang lebih tinggi (Mujito, 2014). Pendidikan di MI lebih memerlukan pembiasaan karena pada saat usia anak 6-12 tahun tidak banyak materi yang diajarkan namun lebih ke hal pembiasaan dengan kasih sayang yang tidak hanya memaksa seoranng anak dalam mengamalkan materi yang sudah diajarkan. Untuk mendukung terciptanya proses pembelajaran yang baik, maka harus ada sinkronisasi antara kurikulum 2013, pendidikan agama islam, dan proses pembentukan kepribadian peserta didik yang direncanakan dan disusun sejak dini dan usia dasar.

Dalam tujuan pembelajaran khususnya di tingkat Madrasah Ibtidaiyah (MI), selayaknya mampu menampung aspek pengetahuan, sikap, dan keterampilan yang sesuai dengan pandangan hidup suatu Negara (Hendratmoko et al., 2017). Ditambah pendidikan di Indonesia sudah masuk pada pendidikan abad ke 21, maka 
pembelajaran harus mampu meningkatkan skill atau keterampilan siswa baik dalam berpikir kritis, berkomunikasi dan kreatif.

\section{KESIMPULAN}

Konsep pendidikan menurut Ki Hajar Dewantara yaitu: a) memajukan budi pekerti setiap manusia yang berarti bersatunya gerak pikiran dan kehendak, yang kemudian menimbulkan tenaga; b) memajukan cara berfikir manusia dengan berpikir realitas, cerdas dan kecerdasannya itu membebaskan dirinya dari ketidaktahuan; dan c) dari pemikiran Ki Hajar Dewantara tersebut dapat diklarifikasi bahwa pemikiran tersebut masih relevan hingga saat ini. Dilihat dari pemikiran-pemikiran beliau yang sesuai dengan konsep yang reevan jika diterapkan dipendidikan MI, di pendidikan MI perlu adanya teladan dalam mendidik, kasih sayang yang tinggi serta pendidikan yang tidak memaksakan kehendak namun menumbuhkan kesadaran. Karena pendidikan itu sangatlah penting, maka sebagai sebuah sistem yang mengandung pendidikan dan pengajaran haruslah lebih memperhatikan makna dari hakikat pendidikan dan pengajaran itu sendiri. Pendidikan di jenjang MI, guru tidak hanya mengajarkan materi yang disampaikan namun harus lebih dalam lagi dalam mengimplementasikan materi menjadi sebuah pembiasaan yang dilaksanakan

\section{DAFTAR PUSTAKA}

Ainia, D. K. (2020). Merdeka Belajar dalam Pandangan Ki Hadjar Dewantara dan Relevansinya bagi Pengembangan Pendidikan Karakter. Jurnal Filsafat Indonesia, 3(3), 95-101.

Dewantara, K. H. (1967). Kebudayaan. Majelis Luhur Persatuan Taman Siswa.

Dewantara, K. H. (1977). Pendidikan. Majelis Luhur Persatuan Taman Siswa.

Hendratmoko, T., Kuswandi, D., \& Setyosari, P. (2017). Tujuan Pembelajaran Berlandaskan Konsep Pendidikan Jiwa Merdeka Ki Hajar Dewantara. JINOTEP: Jurnal Inovasi Dan Teknologi Pembelajaran, 3(2), 152-157.

Idris, M. (2014). Konsep Pendidikan Humanis dalam Pengembangan Pendidikan Islam. Jurnal Miqot, 38(2), 418.

Mujito, W. E. (2014). Konsep Belajar Menurut Ki Hadjar Dewantara dan Relevansinya Dengan Pendidikan Agama Islam. Jurnal Pendidikan Agama Islam, 11(1), 65-78.

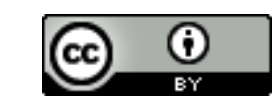




\section{Al-AzkiJa: JURWAL ILFIAH PEHDIDIKAW MIISD \\ ISSI: Print (2145-1656) Online (2521-8110) \\ Vol. 6 i 10.22021 \\ DOI 10.32505/al-akkiva.v62.2.3056}

Muthoifin, M., \& Jinan, M. (2015). Pendidikan Karakter Ki Hadjar Dewantara: Studi Kritis Pemikiran Karakter dan Budi Pekerti Dalam Tinjauan Islam. Jurnal Studi Islam, 16(2), 171.

Nurhalita, N., \& Hudaidah, H. (2021). Relevansi Pemikiran Pendidikan Ki Hajar Dewantara pada Abad ke 21. Edukatif: Jurnal Ilmu Pendidikan, 3(2), 298-303.

Samho, B., \& Yasunari, O. (2010). Konsep Pendidikan Ki Hadjar Dewantara dan Tantangan-Tantangan Implementasinya di Indonesia Dewasa Ini. Universitas Katolik Parahyangan Bandung.

Subandi, S. (2017). Menderadikalisasi Faham Radikal Melalui Pendidikan Multikultural dan Karakter Lokal di Lampung. FIKRI: Jurnal Kajian Agama, 2(2), 457-484.

Sugiarta, I. M., Mardana, I. B. P., Adiarta, A., \& Artanayasa, I. W. (2019). Filsafat Pendidikan Ki Hajar Dewantara (Tokoh Timur). Jurnal Filsafat Indonesia, 2(3), 124-136.

Suparlan, H. (2015). Filsafat Pendidikan Ki Hadjar Dewantara dan Sumbangannya Bagi Pendidikan Indonesia. Jurnal Filsafat, 25(1), 63.

Suroso, S. (2011). Pemikiran Ki Hadjar Dewantara tentang Belajar dan Pembelajaran. Scholaria: Jurnal Pendidikan Dan Kebudayaan, 1(1), 46-72.

Susilo, S. V. (2018). Refleksi Nilai-nilai Pendidikan Ki Hadjar Dewantara dalam Upayaupaya Mengembalikan Jati Diri Pendidikan Indonesia. Jurnal Cakrawala Pendas, $4(1), 33-41$.

Suwahyu, I. (2018). Pendidikan Karakter dalam Konsep Pemikirian Pendidikan Ki Hajar Dewantara. INSANIA: Jurnal Pemikiran Alternatif Kependidikan, 23(2), 192-204.

Utami, P. N. (2017). Konsep Pendidikan Karakter Menurut Ki Hajar Dewantara. Institut Agama Islam Negeri Salatiga.

Yanuarti, E. (2017). Pemikiran Pendidikan Ki. Hajar Deantara dan Relevansinya dengan Kurikulum 13. Jurnal Penelitian, 11(2), 237-266.

Yohana, N. (2017). Konsepsi Pendidikan Dalam Keluarga Menurut Pemikiran Ki Hadjar Dewantara dan Hasan Langgulung. Jurnal Ilmiah Kajian Islam, 2(1), 5.

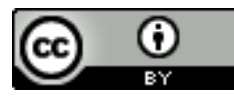


